\title{
American Labor and Working Class History at Iowa: Part II
}

JOHN N. SCHACHT


History Department was best known nationally as the home of the "Iowa School" - primarily William O. Aydelotte, Allan G. Bogue, and Samuel P. Hays-a group credited with substantial innovations in the application of quantitative techniques to the study of history. It was primarily political history to which they brought their new techniques, though Hays (Ph.D., Harvard, 1953), an Americanist focused on the 1877-1920 period, had developed an interest in social history (not labor history) by the time he left Iowa for the University of Pittsburgh in 1960.42

Hays' replacement, Christopher Lasch (Ph.D., Columbia, 1961), was the first Iowa History faculty member in over forty years to write American labor history for publication. His "The Decline of Dissent" (Katellagate, winter 1966/67, pp. 11-17) briefly compared the American Federation of Labor and the American Farm Bureau Federation. After Lasch left Iowa in 1966, an expanded version of this piece appeared in his collection The Agony of the American Left, where it received notice, in the New York Times and in a Labor History review essay, as an early example of "corporate liberal" labor history. A much larger labor history piece to emerge from the History Department in the mid-1960s was Joseph H. Cash's outstanding 1966 Ph.D. dissertation, completed under the direction of Malcolm J. Rohrbough, examining a South Dakota gold mine

${ }^{42}$ Robert P. Swierenga, Quantification in American History (New York: Atheneum, 1970), pp. xv, 1; William Silag, "Pioneers in Quantitative History at the University of lowa," Annals of lowa 46 (1981): 121-23. 
and its workers from 1877 to 1942 . Subsequently published as Working the Homestake (Ames: Iowa State University Press, 1973), it is largely a straightforward institutional account, with an admixture of concerns characteristic of the then-emerging historiography of the working class. ${ }^{43}$

By 1970 there were on campus several History Department graduate students with an interest in the history of working people, including myself, and more were to arrive during the 1970s. I believe I am right in saying their interest was largely engendered by the turmoil of the 1960s, in much the same manner as was occurring at the national level, described above. (I know this was roughly what happened in my own case.) But at Iowa the results were different. While at the national level the scholarship of the 1970s was mostly in the working-classhistory vein, with a large minority still devoted to institutional history (now mostly devoid of its consensatarian trappings), at Iowa the great majority was institutional (similarly devoid of consensatarian trappings), with a small minority in the working-class-history vein. Accounting for this apparently odd pattern is-necessarily speculative but it does not seem terribly difficult. For one thing, locally available manuscript, archival, and oral history sources lent themselves more readily to institutional history. More important, the great majority of scholarship, and certainly the best-known scholarship, in the field then available was institutionalist in orientation, and a graduate student was not likely to be exposed to much of the just-emerging working class historiography unless he had a knowledgeable, committed guide. And most important, there was no such working-class-history-committed guide on the History faculty during the 1970s, to nudge graduate students toward reading or writing the new working class history. Of the eight or nine Americanists who served on the History faculty during the decade, none held more than a passing

\footnotetext{
${ }^{43}$ New York Times, Jan. 22, 1970, p. 35; Zieger, "Workers," 248-51.
} 
interest in working class history (though several maintained strong interests in other branches of social history.)

There was one faculty member, however, who maintained what might be called a secondary research interest in institutional labor history; and the graduate students of the 1970s who had an interest in American working people tended to gravitate toward him (as did some in the 1980s also). This was Ellis W. Hawley (Ph.D., Wisconsin, 1959), who came to Iowa in 1969 and has specialized in post-1920 American history. While his book-length publications do not treat labor history in detail, and he is in no strict sense a "labor historian," his central research interests have touched, at points, on labor history. As Hawley explained his interest in labor history during a December 1989 interview,

I've come at it from a study of organization and bureaucracy.

In other words: an interest in the development of an organizational society in the twentieth century, and the efforts that have been made to fit labor into that, and how labor has fitted into it. I have been particularly interested in Herbert Hoover and his attitudes toward labor, his efforts to find an organizational role for labor.

This interest led to his writing the labor history article, "Secretary Hoover and the Bituminous Coal Problem, 1921-1928" (Business History Review, 42 : 247-70). Earlier, while teaching at the University of North Texas from 1957 to 1968, Hawley had developed an interest in farm labor, particularly the bracero question, which he discussed in his "The Politics of the Mexican Labor Issue, 1950-1965" (Agricultural History 40 (1966): 157-76). ${ }^{44}$

Working under Hawley's direction, graduate students researching the history of working people have produced scholarship that is mostly, though not exclusively, in the institutional vein. Three Hawley-directed seminar papers in the field have reached publication. They are Carolyn Grin's “The Unemployment Conference of 1921: An Experiment in National

\footnotetext{
${ }^{44}$ Ellis W. Hawley, typescript of tape recorded Dec. 13, 1989, interview by the author in Iowa City, pp. 1-2.
} 
Cooperative Planning" (Mid-America, 55 [1973]: 83-107), my own "Toward Industrial Unionism: Bell Telephone Workers and Company Unions, 1919-1935" (cited earlier), and Wilson Warren's "The Welfare Capitalism of John Morrell and Company, 1922-1937 " (Annals of lowa, 47 [1984]: 497-517). Seminar papers which have not reached publication have dealt with Herbert Hoover and labor organization from 1929 to 1932; the development of Ohio's Farm Labor Organizing Committee; the bases of settlement in American labor disputes from 1922 to 1926; and a shooting death during a 1948 meatpacking strike in Waterloo which might have been expected to lead to a racial explosion but did not. Hawley has directed two completed Ph.D. dissertations in labor history. One, my own (cited above), has reached publication, and the other, Bruce Bustard's "The Human Factor: Labor Administration and Industrial Manpower Mobilization during the First World War" (1984) is of publication quality and may well be published in revised form within a few years. Hawley is currently directing a third Ph.D. dissertation - an outgrowth of the seminar paper on Ohio's Farm Labor Organizing Committee. ${ }^{45}$

The seminar paper and incipient Ph.D. dissertation dealing with Ohio's Farm Labor Organizing Committee, along with Wilson Warren's seminar paper-article on Morrell, do combine some of the features of working class history with the standard features of institutional history. Moreover, one other Iowa Ph.D. dissertation in history, completed by Dorothy Schwieder in 1981 and directed by Rohrbough, is very clearly in the working-class-history vein. Focusing on Iowa coal miners, their wives, and their families, it was published as Black Diamonds: Life and Work in Iowa's Coal Mining Communities, 1895-1925 (Ames: Iowa State University Press, 1983). ${ }^{46}$

${ }^{45}$ Ibid, pp. 2-3.

${ }^{46} \mathrm{Ibid}$, p. 2; Stromquist interview, p. 15. Though labor-working class history has not been of central interest to Rohrbough, his own Aspen: The History of a Silver Mining Town, 1879-1893 (New York: Oxford University Press, 1986) devotes some twenty pages to such working-class-history concerns as miners' families, recreation, and on-the-job activities. 
Thus we may allow that persons working within Iowa's Department of History did generate some scholarship in the working-class-history vein, without benefit of a committed, seasoned historian of the working class on the premises. The historian who now fits that description-Shelton Stromquist, who joined the History faculty in 1982-carried this point somewhat further in a November 1989 interview, saying that working class historiography was bound to assert itself at Iowa, as it very decidedly did during the 1980 s, quite aside from the presence or absence of

...an individual whose interests happen to be in that field coming into a university. The stuff is in the air. The books are out there. The monographs are out there. People are reading them. They're interested in these new approaches. A set of circumstances develops in which movement in that direction begins to feed on itself. I think the students themselves feed on each other's work as much as they feed on the work of a faculty member who's acting as a mentor for some of that work. ${ }^{47}$

We may grant Stromquist's essential point but should stipulate, I think, that the presence or absence of a "mentor" can be very important in matters of degree and timing. At Iowa in the 1970 s, labor and working class history had an unusual tiltstrong on "labor," weak on "working class" - due largely to the presence of the strong institutionalist Hawley and the absence of a strong historian of the working class, such as Stromquist. Stromquist himself concedes the fact of a late start in working class history at lowa during the 1970s. "We missed a stage at Iowa," he avers. "We missed what you might term the 'classic new labor history' era." During the 1980s, working class history finally did assert itself fully at Iowa, no doubt stimulated partly by the general proclivities to which Stromquist alludes - but also due to other factors, among them Stromquist's own presence on the scene. ${ }^{48}$

${ }^{47}$ Stromquist interview, p. 13.

${ }^{48}$ Ibid. 
Stromquist is a member of the "Pittsburgh School," in that he studied under David Montgomery at Pittsburgh, received his Ph.D. there in 1981, and was drawn in his research to the workplace (or "shop floor") struggles of late nineteenth century railroad workers. But Stromquist as a graduate student was also attracted by the insights and methodologies that Samuel P. Hays had carried from Iowa to Pittsburgh. (Hays by the late 1970s had for many years been History chairman at Pittsburgh, and he was the prime architect of a department that was very strong in social history.) And some of Stromquist's graduate work was in the Gutman tradition of communitycentered analysis. (He scrutinized several Iowa railroad towns, among others.) Approaches associated with all three older scholars found expression in Stromquist's Ph.D. dissertation, which he revised while at Iowa and published as A Generation of Boomers: The Pattern of Railroad Labor Conflict in NineteenthCentury America (Urbana: University of Illinois Press, 1987). At Iowa, Stromquist has taught courses in American social history and on the United States from 1877 to 1920. And he brought a two-semester sequence of labor and working class history courses into the History curriculum for the first time ever, beginning in $1983 .{ }^{49}$

Perhaps because of his own eclectic background within the broad confines of working class history, Stromquist has been a keen and not always hostile observer of the sharp criticism and fragmentation which has beset the field in recent years. His own recent scholarship, focusing on the working-class component of urban Progressive-era reform, reflects the new interest in bringing politics into the field. And where the interests of his students have diverged from the traditional foci of working class history, those interests have generally been encouraged, not discouraged. One suspects that this open-gauged approach has helped swell the large numbers of graduate students who have sought his guidance, formally and informally, not only

\footnotetext{
${ }^{49}$ Ibid, pp. 8-9.
} 
coming from the History Department but from Sociology, Women's Studies, American Studies, and other programs. Insofar as Stromquist has sought to project thematic coherence, it has been, in his words, "in very broad terms to encourage an analysis of the social history of American life in the late nineteenth and early twentieth centuries that has class, and class division, as its center." A sampling of topics undertaken with his guidance as Ph.D. dissertations in History is: the class context of Civil War recruitment and demobilization in several lowa towns; class formation and ideology in nineteenth century Fort Dodge; the social relations of production and labor organization in Puerto Rico's cigar industry, 1890-1914; and the "problem" of labor violence in Progressive-Era America. Stromquist also played some role in several of the works in Women's Studies and American Studies described below. ${ }^{50}$

During the last quarter of the twentieth century, the proximity of an activist State Historical Society has been stimulating labor and working class history at Iowa, as it did under Shambaugh's leadership during the century's first quarter. The widely separated stimuli are dissimilar, however, except in their like effort at bringing Iowans closer to their own history, and their enlistment of nearby, University-affiliated scholars in that effort. The more recent effort involves the Society's contribution of a great deal of space and staff time to the huge and in some ways unparalleled Iowa Labor History Oral Project (ILHOP). Funded by the Iowa Federation of Labor with over $\$ 196,000$, the project successively employed three young historians, who spent the years 1977 to 1984 conducting oral history interviews with Iowa union leaders and rank and file workers across the state, and collecting such historical records as they could unearth in the process. An oversight committee that included Hawley, and then Stromquist and Roberta TillRetz, monitored the quality of the interviews and collecting. The result is a magnificent, though still largely unprocessed,

${ }^{50}$ Ibid, pp. 9-12. 
assemblage of source material in labor and working class history, now located at the State Historical Society building in Iowa City: 953 tape recorded interviews, with 819 of them transcribed, totaling 40,000 pages; 125 discrete collections of records of local unions, city central bodies, individuals, and the State Federation of Labor, totaling 400 linear feet; and sundry printed, photographic, and audiovisual materials totaling over sixty linear feet. Their value for institutional history is obvious. But further, their great volume imparts such a density to the coverage of individual communities and shop floors in individual industries - 190 interviews and ten record collections deal with Iowa's packinghouse industry, for instance-that they are of great value as a source of working class history as well. ${ }^{51}$

The presence of such a rich resource has served to strengthen and stimulate research in the field, and will continue to do so, particularly if funds to support further processing can be found. Stromquist is in the final stages of a book, tentatively entitled "Passing It On": An Oral History of lowa Labor in the Twentieth Century, which is drawn from the ILHOP interviews, and several of the research projects mentioned in this essay have employed various ILHOP materials. ILHOP also brought to Iowa City as interviewers two historians who have remained there as part of Iowa's community of labor historians-Greg Zieren and Merle Davis. Zieren (Ph.D., Delaware, 1981) has served as a visiting professor at Grinnell, Coe, and Iowa while living in Iowa City, has held a Fulbright Fellowship, and has written "The Boycott and Working-Class Solidarity in Toledo, Ohio in the 1890's" (in Life and Labor: Dimensions of American Working-Class History, ed. by Charles Stephenson and Robert Asher [Albany: State University of New York Press, 1986], pp. 131-149) and "A Century of Meatpacking and Packinghouse Labor in Chicago: A Review Essay" (Annals of lowa, 49 : 692-709). Davis now works at the Society and has published

${ }^{51}$ Conversations with Merle Davis and Mary Bennett, of the Society, in May 1989; unpublished, undated assessment by Shelton Stromquist. 
"You Were Just One of the Unfortunate Ones" (Palimpsest, 70 : 96-102), a study of hoboes who eventually found steady jobs in Iowa.

Both men have participated in the multifaceted "outreach" effort of labor and working class historians at lowa. Zieren was a speaker, like Hawley and Stromquist, at the first of three "Iowa Labor History Workshops," held in Iowa City beginning in 1983, co-sponsored by the Iowa City Federation of Labor and the Democratic Socialists of America. (Stromquist and Roberta Till-Retz, of the Labor Center, have played leading roles in the organization of the workshops.) The workshops have dealt with such subjects as "oral history and the Iowa labor movement," unionization of University of Iowa employees and Iowa City municipal employees, and meatpacking strikes in Waterloo, Iowa, and Austin, Minnesota. People active in those events participated in the workshops. Another outreach effort has been the production of a special, labor-focused issue of The Goldfinch (February 1989), the State Historical Society's magazine for school-age children, in which Davis participated, as did Stromquist. Other outreach efforts have included a photographic exhibition, displayed at numerous Iowa locations during 1985-86 and again in 1990, showing men and women at work in Dubuque in 1912. The photographs were assembled and mounted by Mary Allison Farley in the course of researching her 1985 M.A. thesis in American Studies, "Wage-Earning Women in Dubuque, Iowa, 1910-1917: Their Position in the Labor Force and How They Remember that Experience." Part of the exhibit and the M.A. thesis later saw publication as "Iowa Women in the Workplace" (Palimpsest, 67 : 2-27). And in 1986 Farley joined with Mary Bennett, of the State Historical Society, to produce the Society-supported 'It's a Woman's War Too" - a widely distributed, 60-minute videocassette featuring Farley's interviews with four Iowa women whose work contributed to the war effort during World War II. ${ }^{52}$

${ }^{52}$ Osha Davidson, "Of Course They Didn't Overpay You," Iowa Alumni Review, Nov./Dec. 1985, pp. 13-15; conversations with Mary Bennett, Jan. 1990. 
Scholars associated with the American Studies program have in recent years produced significant scholarship in working class history. Lynne M. Adrian's 1984 Ph.D. dissertation, "Organizing the Rootless: American Hobo Subculture, 18931932," argues that hobo subculture was shaped largely by the American economy's need for large numbers of mobile workers between the depressions of the 1890s and the 1930s. She pursues this and other themes in her introduction to Charles Elmer Fox's autobiographical Tales of an American Hobo, published by the University of Iowa Press in 1989. In 1990, the Press published A Rural Carpenter's World: The Craft in a Nineteenth-Century New York Township, by Wayne Franklin. A professor of American Studies and English at Iowa, Franklin uses the 1869 diary of James C. Holmes as a starting point for exploring the material culture and everyday work experiences of Holmes and his fellow carpenters in an isolated New York community. These two Press publications in labor and working class history appeared within months of one another-after only one publication in the field during the Press's previous twenty-three year existence (Harry Graham's The Paper Rebellion of 1970)-another indicator, perhaps, of rising interest in the field.

At Iowa there has been considerable scholarship at the points of "overlap" between women's history and labor and working class history. Most of it has been undertaken by advanced graduate students in History, or Women's Studies, or American Studies - or in a combination of those programs - and most has been written from a feminist point of view. Much of this work has been under the guidance of Linda Kerber (Ph.D., Columbia, 1968), who joined the Iowa History faculty in 1971 and is now affiliated with the American Studies and Women's Studies programs as well. (Several graduate students have worked under both Kerber and Stromquist.) Work that has reached publication includes Neil Basen's "Kate Richards O'Hare: The 'First Lady' of American Socialism, 1901-1917" (Labor History 21 : 165-199), and that of Kate Rousmaniere, an undergraduate: 'The Muscatine Button Workers' Strike of 
1911-12: An Iowa Community in Conflict" (Annals of Iowa 46 : 243-62). Unpublished seminar papers include a study of gender conflict in Iowa's United Packinghouse Workers locals from 1945 to 1973, and a study of a 1902 telephone operators' strike in Des Moines. ${ }^{53}$

A subject of great historical interest at Iowa has been the working lives of rural women. (Whether this is in all cases "working class" history, strictly speaking, is dubious, but even the farm-owning women under scrutiny here unquestionably performed hard, repetitive labor for most of their lives.) Published work in this vein by Iowa graduate students includes Patrick Nunnaly's study of farm women's labor moving out of their homes and into regional creameries, "From Churns to 'Butter Factories': The Industrialization of Iowa's Dairying, 1860-1900" (Annals of Iowa 49 : 555-69); Judy Nolte Lensink's revised Iowa Ph.D. dissertation, A Secret to be Burried: The Diary and Life of Emily Hawley Gillespie, 1858-1988 (Iowa City: University of Iowa Press, 1989), a recent winner of the Shambaugh Award for the best book published on Iowa history in 1989; and Katherine Jellison's "Women and Technology on the Great Plains, 1910-40" (Great Plains Quarterly 8 [1988], 145-57). Jellison's article is the precursor of a very ambitious Ph.D. dissertation, now in its late stages, on the impact of technology on the lives and labor of rural women during the twentieth century. Iowa's status as a center for the study of rural women gained signal recognition in 1988 with the award of a $\$ 250,000$ Rockefeller Foundation Resident Fellowship Program, to support the Women's Studies Program's Feminist Theory and Rural Issues Project, under the direction of Margery Wolf, Professor of Women's Studies and Anthropology. (Iowa women's historians are not alone in their interest in rural America. An historian writing in the New York Review of Books recently noted that, all over the United States, "social historians are, figuratively speaking, moving to the country.") One of the two

\footnotetext{
${ }^{53}$ Linda Kerber, typescript of tape recorded Dec. 29,1989 , interview by the author in Iowa City, pp. 6-8.
} 
fellows brought to Iowa during the project's first year was Deborah Fink, an anthropologist who shared her strong interest in working class history with the students she came in contact with at Iowa. Earlier, she had written Open Country, Iowa: Rural Women, Tradition and Change (SUNY Series in the Anthropology of Work; Albany: State University of New York Press, 1986), which examines how the twentieth century's transformation of American agriculture has, in effect, proletarianized large numbers of rural women. ${ }^{54}$

There would seem to be ample support, then, for Benjamin Hunnicutt's contention, and my own, that "there is a lot that's happening" in American labor and working class history at Iowa. As for Hunnicutt's own place in the labor history-vis-avis-working class history schema: He works mostly within the working-class-history tradition. A professor of leisure studies, he is, after all, centrally concerned with workers' lives off the job. But his research has necessarily involved him in examining the pressures that labor organizations have exerted on behalf of shorter (or longer) hours, and at points he has relied heavily on the work of institutional economists. Hunnicutt's research has recently drawn him into an extensive investigation of workers' lives in situations where unusually short work days have long been in effect, notably among tire workers in Akron, Ohio, and among Kellogg cereal workers in Battle Creek, Michigan. A related interest is in mythologies that have grown up in the twentieth century surrounding work in the United States. ${ }^{55}$

Libraries do not grow. Growth is a function of organisms and occurs naturally, unconsciously, guided largely by genetic control systems. As John C. Colson has pointed out, increase, by contrast, has been the common condition of libraries' development, especially increase in the numbers and diversity of materials held in them. This has been a process controlled by

${ }^{54}$ Ibid, pp. 5-7. George M. Frederickson, "Down on the Farm," New York Review of Books, April 23, 1987, p. 37.

${ }^{55}$ Hunnicutt interview, pp. 1-2, 5-6. 
human will, and usually one in which the wills of two or more people were involved. That is, library increase has been a social and intellectual process. ${ }^{56}$

Long before even such early labor historians as Downey and Haynes had begun their research, librarians at Iowa, owing largely to a continuing dialog with the History faculty, had taken steps that would eventually prove useful to scholarship in labor and working class history. By 1859, they had discovered that, even faced with the most parsimonious book budgets, they could usefully devote their energies to acquiring free copies of federal and state government publications. By 1870 , they had discovered that in the Departments of History and Political Economy, decreasing use was being made of textbooks, and more stress was being placed on "the examination of original authorities." By 1871, there had begun the splendid, still-continuing tradition of History faculty members' lobbying librarians and University administrators for more funds to be devoted to the purchase of history-related materials. Andespecially important for such a then-controversial subject as labor organizations-librarians by 1871 had concluded that "there should be sought books written from different and even opposite standpoints, that the investigator may be able to save himself from one-sided and hence incorrect views and conclusions." 57

No reader of Books at Iowa will need to be convinced that, in general, the character of locally accessible library collections at a university helps shape the character of research and teaching at that university. The point is as true with respect to American labor and working class history as it is to any other field. Wisconsin's Ely-Commons-Perlman group could not have been the researchers and teachers they were without benefit of the collections gathered at the State Historical Society of Wisconsin

${ }^{56}$ Colson, "Academic," p. 3.

${ }^{57}$ The quotes are from UI's University Reporter, 3 (no. 3, 1870): 42, and Report of the State University of lowa, December 20,1871, p. 124, in Mildred Throne, "The History of the State University of lowa: The University Libraries" (M.A. thesis, UI, 1943), pp. 31 and 13-14. See also pp. 9, 32-33. 
(SHSW). Scholars at Iowa, from Loos to Schlesinger, depended on books and government publications available at the University Libraries, in writing their own articles and book chapters in the field. Several of Hawley's graduate students have relied on archival materials held at the Herbert Hoover Presidential Library in nearby West Branch. I could not have written The Making of Telephone Unionism without the materials gathered by the Communications Workers of America-University of Iowa (CWA-UI) Oral History Project, now housed in the Special Collections Department of the University Libraries. And the graduate students working under Hawley, Stromquist, and Kerber who have been studying workers in the meatpacking industry have relied on the ILHOP materials amassed at the State Historical Society of Iowa.

A less obvious point, perhaps, is that the character of research and teaching taking place at a university-and of some of its service functions as well-can and does shape the locale's library collections. Developments at Wisconsin from 1904 to 1913 perhaps illustrate the point in boldest relief: Yes, the Ely-Commons-Perlman group needed the SHSW collections; on the other hand, the SHSW collections would not have been there but for the efforts of the Ely-Commons-Perlman group of scholars in the first place. But that was during a simpler age. How, we may ask, have the University of Iowa Libraries' collections been shaped in recent decades by the University's research/teaching/service activities as they relate to labor and working class history?

For one thing, a significant share of the money spent on expensive research materials has gone toward purchasing labor and working class history materials, including materials which "overlap" women's history-and this is in large measure a response to the fact of these being active teaching and research fields at Iowa. That is, librarians, in trying to make balanced collection development decisions, do weigh the fact that faculty members teaching in these fields are persistent in suggesting Iowa graduate students' present and future need for such materials, and they weigh the fact that when funds can 
occasionally be found to actually purchase such facultyrecommended materials, graduate students and some undergraduates are observed using the materials. This process, requiring as it does librarians' sensitization to what is going on in a variety of fields on campus and beyond, is best described, I think, as social and intellectual (and is in no sense organic or "scientific"). In any event, it accounts for the Libraries' holding many of the large sets of microfilm cited below, sets which for the most part reproduce important archival and manuscript collections housed in their original form at such institutions as the SHSW. Similarly, the Libraries' participation in such consortiums as the Center for Research Libraries (CRL), in Chicago, has been influenced by research and teaching activity in labor and working class history at Iowa. It was at the Libraries' request, for example, that the CRL began purchasing installments of microfilm which reproduce the 1918-66 records of the Women's Bureau of the U.S. Department of Labor-a request that was prompted by the expressed interest of researchers in Women's history/labor history at Iowa.

The Libraries' collections have been affected in a different way by such faculty members as Daykin and Sinicropi. Daykin helped establish Iowa's Bureau of Labor and Management, essentially a service organization. The labor-related records of that unit, from 1952 to 1972 , now reside in the University Archives, a division of the Libraries' Special Collections Department, where they constitute a valuable source for the study of the history of labor union education efforts. The interview transcripts created by the CWA-UI Oral History Project would not now reside in Special Collections, indeed would never have been created at Iowa, had it not been for the Bureau's and Sinicropi's presence on the Iowa scene during the 1960s. The same may be said of Sinicropi's case files as a labor arbitrator from 1965 onward, which are presently accumulating in Special Collections. The acquisition of original archival, oral history, and manuscript materials, such as these, materials uniquely held by The University of Iowa Libraries, is of course also due to the efforts of Special Collections' professional personnel- 
people who are well aware that at Iowa there is present and potential interest in labor and working class history materials such as these.

The three collections mentioned above, along with twentyfour other labor and working class history-related collections uniquely held by Special Collections - and comparable collections at the Hoover Library and the State Historical Society of Iowa (such as the ILHOP materials)-are described in my "Labor History Resources in the University of Iowa Libraries, The State Historical Society of Iowa/Iowa City, and the Herbert Hoover Presidential Library" (Labor History, 31 : 168-75). They will not be re-described here, though a recent arrival in Special Collections should be mentioned: the papers of Lem Harris, a Communist author and organizer among farmers and agricultural workers, who was primarily associated with the United Cannery, Agricultural, Packing and Allied Workers of America (3 ft., 1919-85).

Aside from items described in the above-mentioned article, the Hoover Library and the State Historical Society hold nothing of unusual interest from the standpoint of labor and working class history, so far as I can determine, with one exception: The society has a microfilm copy of the personal papers of John L. Lewis, 1906-1969 (4 reels of microfilm, original in SHSW). The University Libraries, in contrast, do hold many items which, though not uniquely held and mostly in published form, are nonetheless clearly of unusual interest.

Among them are the standard bibliographical sources, including the somewhat outdated general bibliographies-Labor in America: A Historical Bibliography (Santa Barbara: ABC-Clio, 1985) and Maurice Neufeld's American Working Class History: A Representative Bibliography (New York: Bowker, 1963); such specialized bibliographies as Susan Estabrook Kennedy's America's White Working-Class Women: A Historical Bibliography (New York: Garland, 1981); such archival/manuscripts guides as F. Gerald Ham's and Margaret Hedstrom's A Guide to Labor Papers in the State Historical Society of Wisconsin (Madison: the Society, 1978), Warner Pflug's A Guide to the Archives of Labor History and 
Urban Affairs, Wayne State University (Detroit: Wayne State University Press, 1974), and Andrea Hinding's Women's History Sources: A Guide to Archives and Manuscripts Collections in the United States (New York: Bowker, 1979); the annual bibliographies of American labor and working class history which appear in Labor History; the occasional articles in that journal which introduce or update important archival/manuscript collections held by various institutions across the country (see especially vol. 23, no. 4 and vol. 31, nos. 1/2); and several ongoing, broadly-gauged indexes which are pertinent to the needs of researchers in American labor and working class history: The National Union Catalog of Manuscript Collections, the National Inventory of Documentary Sources in the United States, America: History and Life, Dissertation Abstracts International, and Social Sciences Citation Index. Libraries staff members are capable of searching the computer-database counterparts of the three last-named indexes on researchers' behalf, via computer terminals on library premises. The staff can also search another pertinent index which exists only in database form - the Archives and Manuscripts Control section of the Research Libraries Information Network.

The Libraries hold several large, pertinent sets of microfilm which reproduce manuscript and archival collections held elsewhere. They are: (1) The Papers of T.V. Powderly, 18641937, and John William Hayes, 1880-1921 (109 reels; originals at Catholic University of America), which, in effect, are the national office records of the Knights of Labor, America's largest and arguably most important nineteenth century labor organization. The papers are complemented by "The Knights of Labor Data-Bank," a source of computerized information on the 12,000 locals of the Knights, held by the University's Iowa Social Science Institute. (2) The Collis P. Huntington Papers, 1865-1901 (115 reels; Syracuse University), which contain some material on railroad workers and labor problems on Huntington's Southern Pacific Railroad. (3) The Henry Demarest Lloyd Papers, 1847-1903 (52 reels, SHSW). (4) The Papers of Ignatius Donnelly, 1812-1943 (167 reels, Minnesota Historical Society). 
(5) American Federation of Labor Records: The Samuel Gompers Era (144 reels; American Federation of Labor-Congress of Industrial Organizations [AFL-CIO] national headquarters and the SHSW). (6) The Papers of the Women's Trade Union League and Its Principal Leaders (131 reels; mostly the Schlesinger Library of Radcliffe College). (7) Hawthorne Study Records (186 microfiche; University of WisconsinMilwaukee), which document industrial productivity and psychological studies among workers at Chicago's Western Electric plant from 1927 to 1932. (8) Operation Dixie: The C.I.O. Organizing Committee Papers, 1946-1953 (75 reels, Duke University). In addition, the University of Iowa Law Library holds Selected Documents of Records of the Committee on Fair Employment Practice, 1941-1946 (213 reels, National Archives).

'The Libraries' holdings of periodicals pertaining to American labor and working class history are not outstanding by comparison with other large research libraries but are nonetheless very substantial. Anyone seeking a particular periodical in this field, even a seemingly obscure one, would be poorly advised to assume it is not in the Libraries. Its title should be checked in the public card catalog and OASIS (the computerized cata$\log$ ) and, if that fails, the name of any institution associated with it should be checked. Failing that, a reference librarian should be consulted for other possibilities. For the researcher who does not have particular titles or institutional names in mind, approaching the card catalog and OASIS via subject headings is a possibility. Many, though unfortunately not all, periodical holdings pertinent to American labor and working class history are listed at Labor and Laboring ClassesPeriodicals, Labor and Laboring Classes-United StatesPeriodicals, Trade-unions-Periodicals, Trade-unions-United States-Periodicals, and at the series title Radical Periodicals in the United States. (Some important periodicals cannot be approached via any subject headings.)

Pertinent periodical holdings are too numerous to list here in their entirety. What follows is a listing of holdings of particular importance, along with a few titles intended to reinforce the 
suggestion that the Libraries do hold long runs of some seemingly obscure periodicals one might not normally expect to find at Iowa. Industrial Workers of the World periodicals include The Industrial Union Bulletin (1907-09), Industrial Worker (1909-13), The Industrial Union News (1912-24), The Industrial Pioneer (1921-26), and The One Big Union Monthly (1919-21, 1937-38). American Federation of Labor/Congress of Industrial Organizations periodicals include American Federationist (1894-

), C.I.O. Newos (1945-55), AFL-CIO News (1955- ), I.U.D. Digest (1956-63), I.U.D. Bulletin (1956-64), IUD Agenda (196568), and Viewpoint (1971-82). Holdings of periodicals issued by individual labor unions include The Conductor and Brakeman (1884-1964, occasional vols. missing), United Mine Workers Journal (1891- ), The Railroad Trainman (1939-48), Justice (International Ladies Garment Workers Union, 1944-57), The International Teamster (1945-86), Advocate (Retail Clerks International Association, 1945-78, many issues missing), Ammunition (United Automobile Workers, 1948-57), International Musician (1948- ), and The Carpenter (1949-81), occasional issues missing). Pertinent miscellaneous periodicals include the Journal of United Labor (Knights of Labor, 1880-1917), Life and Labor Bulletin (Women's Trade Union League, 1933-50), The Catholic Worker (1939- ), The American Labor Legislation Review (Commons' American Association for Labor Legislation, 1911-42), The Southern Workman (Hampton Institute, 1872-1918), National Labor Tribune (1874-1909), The Irish World and American Industrial Liberator (1878-1950), The Appeal to Reason (1895-1917), The Square Deal: Current Discussions of Industrial Problems (1905-16), Labor Age (1913-33), The American Labor Year Book (1916-33), Hobo World (1917-29), Law and Labor (1922-32), The Union Pacific Magazine (1922-1933), Industrial Unionist (1932-50) Management Record (1939-63), Labor Today (1961- ), and Daily Labor Report (1966- ).

The Libraries also hold substantial runs of the convention proceedings of the Order of Railway Conductors, the Industrial Workers of the World, the American Federation of Teachers, the International Ladies Garment Workers Union, the Con- 
gress of Industrial Organizations, the United Auto Workers, and the Iowa Federation of Labor.

Government agencies have long been compilers of masses of information essential to the pursuit of American labor and working class history, and the Libraries' Government Publications Department (along with Iowa's Law Library) is a major repository of such information. It holds such massive and justly famous published compilations and reports as the U.S. Senate Committee on Labor and Education's Hearings on the Relations between Labor and Capital (1883-84, 4 vols.), the U.S. Industrial Commission's Reports (1900-02, 20 vols.), the U.S. Commission on Industrial Relations's Final Report and Testimony (1916, 11 vols.), the [LaFollette] Subcommittee of the Committee on Education and Labor's Violations of Free Speech and the Rights of Labor (1936-39, 78 parts totaling 28,800 pp.), the U.S. National War Labor Board's War Labor Reports (1942-45, 28 vols.), the U.S. National Labor Relations Board's Decisions and Orders (1935- , 286 vols. as of 1987), and various works published by the U.S. Department of Labor, whose Women's Bureau and Bureau of Labor Statistics have long issued particularly valuable series. But there are hundreds, even thousands, of other pertinent U.S. government publications, ordinarily the outcome of investigations by temporary or permanent Congressional, executive, or independent federal agencies. Numerous examples are buried, for instance, in the Bureau of the Census' Publications, particularly those for the 1880s and '90s. (One example is Henry Hall's 276-page narrative, "Report on the Shipbuilding Industry of the United States", containing a sprinkling of statistics and detailed illustrations.) Government Publications and the State Historical Society of Iowa also hold some manuscript census data in microfilm. Some of the better subject bibliographies, such as those by Neufeld and Kennedy cited above, include mention of pertinent U.S. government publications, but any thorough investigation will involve querying Government Publications Department personnel and/or intensive use of the finding aids on the Department's premises. 
The Libraries' holdings of Iowa state documents are nearly complete. These include large, pertinent publications issued by the Iowa Bureau of Labor, the Iowa Employment Security Commission, and the Iowa Public Employment Relations Board. (Most are in Government Publications, some in the Business Library and the Law Library). Holdings of state publications other than Iowa's are sparse, but the Government Publications Department does hold devices for identifying pertinent documents: exhaustive bibliographies for some states, along with the Monthly Checklist of State Publications, which, since 1910, has indexed substantial publications of all states by agency and by subject. ${ }^{58}$

Patient readers will by now have a sense of "how" the outpouring of scholarship in American and working class history has occurred at Iowa. With that base of information, we may pose an answer to the question of why it has occurred and is continuing.

Part of the answer lies in three "background" conditions which obtain at Iowa-but are also present at many or all good colleges and universities. One is the definitional and real expansion of the field. Labor history has been joined by working class history, which has intensively explored broad subject areas uncharted as of thirty years ago. Together, they overlap other expanding fields, such as women's history. In short, the field has expanded from a small one to a large one. It is now practiced by hundreds of scholars nationwide, and it is only natural that some of the expansion should occur at Iowa. A second condition is the high quality of Iowa's faculty. As with many fields at many universities, Iowa in this field employs faculty members who do research and writing, who attract talented graduate students (and some undergraduates), and who guide those students toward making scholarly contributions themselves. A third condition, common to many colleges and many universities, is a tradition of religious and

\footnotetext{
${ }^{58}$ I thank Frank Allen, of the Libraries' Government Publications Department, who provided me with much of this information.
} 
ideological tolerance and diversity which has brought researchers with widely varying backgrounds to the University's staff. Iowa researchers whose names have figured prominently in this essay include a member of the Reorganized Church of Latter-Day Saints, a Jew, a non-believing New Left socialist, and-shattering all known precedents in this field-a churchgoing Episcopalian.

Part of the answer lies also in two circumstances in which Iowa has been unlike most other universities and colleges. First, the proximity of an activist State Historical Society has clearly been a very important spur to labor and working class history at Iowa, through its publication program in the first quarter of the century and through its care of the ILHOP materials during the last quarter. Second, the field at Iowa has been stimulated by lowa's being a large state university with a broad array of academic programs and services. As we have seen, labor and working class history is a field whose practice is not necessarily confined to a university's history department. For long periods, in fact, its practice within history departments has been the exception rather than the rule. With Iowa's breadth, there have been other fields, along with the History Department at times, which have sustained the practice of labor and working class history: in the past, most notably, the College of Commerce/Business Administration; at present, most notably, Women's Studies and American Studies. And service units have augmented the field at Iowa. The Bureau of Labor and Management has played a significant role, as described above. And the University Libraries' staff has worked with teachers and researchers in the field-and with other personnel, such as those associated with the Bureau of Labor and Management - to build a supportive collection.

These latter two circumstances-the proximity of the State Historical Society and the size and breadth of the University's programs and services-have combined with severe twists in the occupational demography of academia in the 1970s and 1980 s to produce yet another circumstance that has favored the development of labor and working class history at Iowa. Iowa's 
community of historians in this field has been much enhanced (I dare say) by the presence of four people who were history graduate students, focused on that field, during the 1970s and early 1980s but who did not find regular employment in their intended vocation - history teaching at the college or university level. What subsequently attracted these people to Iowa City was in large measure the employment opportunities offered by the Society, in the case of Greg Zieren and Merle Davis; by the University's Leisure Studies Department, in the case of Benjamin Hunnicutt; and by the University Libraries, in my own case.

That, of course, does not explain why three of the four maintained an interest in labor and working class history and published in the field, many years after they had left academic history as students and as a vocation. (The fourth, Zieren, has not abandoned academic history as a vocation.) Here, I think, we must return to Hunnicutt's suggestion of the importance of the building up of a kind of critical mass at Iowa, whereby scholarship in the field is encouraged by researchers' mutual presence. Or, in Hunnicutt's more concrete terms:

...the atmosphere here is one of the things that encouraged me to pursue the things that I have pursued, knowing that I would have at least some audience here on campus that would be reading what I wrote-even if no one else in the world did. ${ }^{59}$

Surely, this simple explanation must account for much of the outpouring of labor and working class history in recent years at Iowa, not only among the four men named above, but among the many other students and scholars who have ventured into the field.

An essential task of the academic library is the rational joining of research and resources. What does the foregoing tell us about the nature of that task with respect to American labor and working class history at Iowa in the years ahead?

\footnotetext{
${ }^{59}$ Hunnicutt interview, p. 3.
} 
Aside from the fact of its consistent growth in recent decades, we have seen very little pattern in the development of the field at Iowa. Like the field as practiced at the national level, its practice has been variegated and rather mercurial. Its practitioners have sprung from various and unexpected quarters. Once the field was narrow; now it spills over a goodly portion of Iowa's academic landscape. Research emphases have taken unexpected turns at Iowa, often-but not always -reflecting national emphases.

One thing this tells us, I think, is that librarians must be wary of acquisitions strategies that place themselves in a proactive role or that commit a preponderance of funds or effort toward acquiring materials of one kind. This is not a field in which it is wise to anticipate needs very far ahead. Here, librarians who try to "get ahead of the curve" may discover themselves sitting lonely and lost with their newly purchased materials, and with no one on campus looking for them.

It tells us that we should, when given the opportunity, offer a very carefully measured response to two suggestions that have been-made at the national level. One is that archivists and manuscripts librarians concerned with labor and working class history should join in establishing a national office, perhaps funded by the AFL-CIO, whose principal function would be the nationwide "coordination" of the acquisition of source materials in the field, with an eye toward avoiding duplicated acquisition of similar materials and toward encouraging each repository to specialize in certain kinds of materials. This may make sense from the standpoint of very heavily committed repositories such as the SHSW and Wayne State's Archives of Labor and Urban Affairs (though I doubt it; many materials that have turned out to be valuable probably never would have been collected, given earlier implementation of such a system). Iowa's librarians, in any event, should greet any proposal to thus pre-define and narrow their role with the same skepticism they would reserve for fitting an octopus into a straitjacket. At 
Iowa, acquisitions policies in this field should be kept flexible enough to respond to research and teaching needs as they develop. ${ }^{60}$

Similarly, the suggestion that manuscripts librarians and archivists should now redirect their acquisitions strategies to accommodate the supposed fact that historians "will be increasingly interested in data that illuminates the shadowy realism of working class culture" should be greeted with some skepticism. Certainly, the needs of working class history are something to bear in mind. But those needs are changeable and extremely diffuse. And Iowa in this field does not bear the responsibilities of a leading repository. (Spatial, financial, and geographical factors would seem to bar its becoming a leading repository in the future.) In the absence of specifically stated research and teaching needs, Iowa should not commit substantial resources toward actively seeking such materials. Here, the State Historical Society's experience with ILHOP is perhaps instructive as to the virtues of simply awaiting developments. Originally undertaken as the institutional project par excellence, ILHOP's materials turned out to also be the locally-held original collection of by far the greatest value from the standpoint of working class history-and, potentially, a collection of national prominence in this field as well. ${ }^{61}$

How, then, can we best join library resources to the pursuit of American labor and working class history at Iowa?

First, while we should be wary of anticipating needs, we should be eager to respond to the expressed needs of teachers and researchers in this field-and to respond to opportunities for acquisitions in the field as they arise as well. As the foregoing has, I hope, made clear, in the field of American labor and working class history (as in other fields), the University's research momentum and the University's library re-

\footnotetext{
${ }^{60}$ Thomas Conners, "A National Agenda for Labor Archives: The Tasks of Coordination," The Public Historian 11 (1989): 137-138.

${ }^{61}$ Russell G. Hahn and Gregory S. Kealey, "Documenting Working Class History: North American Traditions and New Approaches," Archivaria, 4 (1977): 99.
} 
sources are interdependent in ways that are sometimes overlooked. We should think in terms of holding up "our" half of that interdependency by doing what we can to maintain the momentum of research in the field, rather than augmenting or retarding it.

Second, insofar as we do think in terms of anticipating needs through acquisitions, we should aim at complementing strong collections that are already present locally and are already of proven interest. The prime opportunities here are with respect to the ILHOP materials. We can see rather clearly that these will be drawing scholars' attention for years to come. And there are strong indications that the massive, intensive subset of ILHOP materials on meatpacking plants, communities, unions, and workers will be of particular interest. The Libraries' role, then, might logically be to acquire the records of meatpacking companies whenever the opportunity arises, and to readily purchase microfilmed copies of manuscript, archival, or oral history materials concerning the meatpacking industry and its workers whenever they are requested or are offered at bargain rates.

Finally, we should recognize that, especially in a field whose practitioners are spread across several programs on campus and off, information as to library holdings, new or old, does not necessarily move rapidly or efficiently. Here, as with all fields the Libraries are committed to support, we must do what we can to alert researchers to substantial holdings in their field. 